\title{
Evaluation of The Implementation of The Inclusion Program
}

\section{Abdul Rokhim ${ }^{1}$, Suryadi2, Supadi ${ }^{3}$}

1,2,3 Education Management, Postgraduate Jakarta State University, Jakarta, Indonesia

\section{ART ICLE INFO}

\section{Article history:}

Received July 14, 2021

Revised July 17, 2021

Accepted September 14, 2021

Available online November 25, 2021

\section{Kata Kunci:}

Evaluasi, Program Inklusi, Siswa Berkebutuhan Khusus

\section{Keywords:}

Evaluation, Inclusion Program, Students With Special Needs

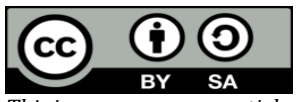

This is an open access article under the $C C$ BY-SA license.

Copyright (ㄷ) 2021 by Author. Published by Universitas Pendidikan Ganesha.

\begin{abstract}
A B S T R A K
Dalam pelaksanaannya, sekolah inklusi banyak kendala yang dihadapi, baik menggunakan kurikulum yang belum sepenuhnya dilaksanakan dengan baik. Guru kurang memahami dan berinovasi dalam menggunakan metode dan media pembelajaran bagi anak berkebutuhan khusus. Kesulitan dalam menyiapkan instrumen penilaian yang baik. Infrastruktur unik yang belum memadai dalam mendukung perkembangan anak menjadi kendala untuk mendukung keberhasilan pelaksanaan pendidikan inklusif. Penelitian ini bertujuan untuk menganalisis konteks, masukan, proses, dan produk dari program Pendidikan Inklusif. Penelitian ini merupakan penelitian evaluasi program dengan menggunakan model CIPP. Metodologi yang digunakan adalah metode survei dan deskriptif. Informan penelitian adalah Kepala Sekolah, wakil kepala sekolah bidang kurikulum dan kemahasiswaan, Bapak dan Ibu guru, guru pendamping khusus. Teknik pengumpulan data melalui observasi, angket, dan wawancara. Teknik yang digunakan untuk menganalisis daya yaitu analisis deskriptif kualitatif. Berdasarkan analisis data, kendala utama program pendidikan inklusi yang dialami sekolah adalah adanya guru pendamping tidak tetap yang hanya menerima satu kali per minggu, sehingga menghambat perkembangan siswa berkebutuhan khusus. Selain itu, sarana dan prasarana yang mendukung proses pembelajaran masih belum lengkap. Keunikan kurikulum pendidikan inklusi perlu dikaji ulang untuk meningkatkan kemampuan belajar anak berkebutuhan khusus.
\end{abstract}

\section{A B S T R A C T}

In practice, inclusive schools face many obstacles, using a curriculum that has not been fully implemented properly. Teachers do not understand using methods and learning media for children with special needs. Be in a good instrument. Unique infrastructure that has not been adequate in supporting child development is an obstacle to implementing inclusive education successfully. This study aims to analyze the Inclusive Education program's context, inputs, processes, and products. This research is a program evaluation research using the CIPP model. The methodology used is a survey and descriptive method. The research informants were the principal, vice-principal for curriculum and student affairs, teachers, special assistant teachers data collection techniques through observation, questionnaires, and interviews. The technique used to analyze power is descriptive qualitative analysis. Based on the data, the problem with inclusive education programs experienced by schools is the presence of non-permanent accompanying teachers who only receive one time per week, thus hampering the development of students with special needs. In addition, the facilities and infrastructure that support the learning process are still incomplete. The uniqueness of the inclusive education curriculum needs to be reviewed to improve children's learning abilities with special needs.

\section{INTRODUCTION}

Children with special needs have both temporary and permanent abnormalities, so that they get more intense attention in the educational process because they are different from other normal children (Pangemanan et al., 2013; Pratama et al., 2021a). Children with special needs are students who have deficiencies both physically, mentally, and socially (Rudiyati, 2013; Septianisa \& Caninsti, 2018). Children with special needs have different skills and potentials that must be developed and improved without considering whether they are normal or have special needs. Children with special needs need an educational environment that can adapt to their obstacles and requirements (Diahwati et al., 2016; Yunita et al., 2019). Based on data from the Central Statistics Agency in Indonesia, the number of children with special needs reaches 1.6 million children, of which 18\% have only received education services, namely 115 thousand children attend special schools and 229 thousand attend inclusive schools.

Special Schools are often referred to as segregational education (Praptiningrum, 2010; Winarsih, 2013). Segregation education separates children with special needs from children in general in the curriculum, learning methods, facilities, and evaluation system (Flores-tena \& José, 2020; Heyder et al., 2020). The implementation of segregation education has unwittingly built an entire wall for children with special needs to hinder the introduction process between children (children with special needs and children 
without special needs) (Ro'fah et al., 2020; Shofa, 2018). That causes social interaction in society; children with special needs become alienated from the dynamics of social life in society (Suastariyani \& Tirtayani, 2020; Winanti et al., 2021). Along with its development, inclusive education emerged, which became an innovation in answering the problems of the segregation education system. With inclusive education, participation from the community is created for education for children with special needs so that various parties have a favorable view of their learning progress (Sulthon, 2019; Widyastono, 2013).

Inclusive education is education intended for children with special needs combined with normal children (Krischler et al., 2018; López et al., 2021). Inclusive education is an educational approach that can provide equal opportunities to all students to achieve academic and social activities, including extracurricular activities, music, sports, social activities (Kratz et al., 2019; Taylor \& Ringlaben, 2012). Inclusive education as uniting children who have barriers/have disabilities who are included in a school program. Inclusive education is a learning technique by presenting children with special needs as part of learning activities and getting the same learning opportunities as normal children (Sivaramakrishnan et al., 2019; Turgut \& Turgut, 2018). One of the goals of inclusive education is to encourage the full participation of children with special needs in community life to improve student learning outcomes. The ultimate goal of inclusive education is the provision of schools in which everyone participates and is treated equally. Thus, inclusive education is a constant process to ensure that education is truly for all children.

The implementation of inclusive education has tremendous implications for the fulfillment of children with special needs (Flores-tena \& José, 2020; Heyder et al., 2020). Inclusive education is an essential element in embracing all parties with special needs to develop their respective potentials and skills. One of the characteristics of inclusive education is a cohesive, accepting, and responsive community to the needs of students. Children with special needs are vulnerable groups of people in fulfilling their rights because they have limited abilities (Hamidaturrohmah \& Mulyani, 2020a; Septianisa \& Caninsti, 2018; Yunita et al., 2019). The challenges of inclusive education in learning activities include the class must remain harmonious considering the diverse class population. Children with special needs require much effort to understand the concepts that have been mastered by the majority of the class (Diahwati et al., 2016; Suprihatiningrum, 2016).

State Elementary School 01 Sungai Bambu is one of the inclusive schools appointed by the DKI Jakarta education office. The appointment as the implementation of inclusive education at SD Negeri 01 Sungai Bambu began in 2013. Based on the 2020 school year data, there are 20 children with special needs, while there is 1 Special Advisor Teacher to handle children with special needs. Types of abnormalities in children are very diverse; there are mentally retarded, physically disabled, autistic, and so on. In its implementation, many obstacles are faced, both using the curriculum that has not been fully implemented properly. Teachers lack understanding and innovation in using learning methods and media for children with special needs. Difficulties in preparing assessment instruments both in the implementation of assignments, mid-semester assessments, and end-of-semester assessments. So that, the assessment process results in children with special needs. Being remedial repeatedly until the teacher gets questions under the type of obstacle in the child impacts children with special needs who only get the maximum score according to the KKM value at the end of the semester. So that the same treatment in the assessment process is not following the ability of children with special needs in inclusive education. The lack of a companion Teacher specialized in assisting children with special needs. Inadequate unique infrastructure in supporting child development is a problem to support the successful implementation of inclusive education. The number of issues found in the performance of inclusive education at the State Elementary School 01 Sungai Bambu is necessary to review and re-evaluate in implementing inclusive education programs at that school.

Several interrelated components, including one influence the success of the implementation of inclusive education). First; the curriculum, which is used to adjust to the level of the education unit by considering regional conditions and children's abilities (Mullett et al., 2021; Patel et al., 2021). With a curriculum adapted to children's needs, the curriculum in inclusive schools can handle problems regarding children with special needs that have been agreed upon by the Principal, classroom teachers, and exceptional teachers (Batterbee, 2020; Ramachandra, 2020). Second; Staff, educators (teachers), and developing students must have competencies in their fields. Teachers must be able to choose a suitable method so that students can develop quickly. Special teachers have special educational qualifications and skills and function as consultants for class teachers, school principals, and children. In addition, special teachers also function as mentors in unique guidance rooms (Rudiyati, 2013; Septianisa \& Caninsti, 2018). Third; Environment and Implementation of Inclusive Education, both parents and the Government, have a role as an increase in children's motivation and confidence and as a policymaker in determining the implementation of inclusive education by providing teachers, budgets, and facilities needed by schools so that inclusive education can run smoothly. Fourth; Facilities and infrastructure, inclusive schools, are different from other public schools. Inclusive schools require certain facilities according to the needs of 
children with special needs in the classroom (Diahwati et al., 2016; Yunita et al., 2019). Fifth; Assessment, as a process of collecting and processing information on student achievement, the effectiveness of the learning process, and feedback and improving decision-makers, both academic and non-academic.

Evaluation is a systematic process determining how far students achieve their educational goals (Maqableh \& Alia, 2021; Wijaya et al., 2021). Evaluation is the highest goal in the cognitive domain; this goal is related to judging something based on specific goals or criteria (Kim et al., 2019; Savul et al., 2021). This goal also includes the ability to decide with various considerations and particular measures (Mulyanto et al., 2020; Tempelaar, 2019). Have the skills and abilities needed to give an assessment? From the focus of this research, the sub-focus of the problems studied are described as follows: Evaluation of the school program environment, legal basis, implementation guidelines, determination of inclusive schools, socialization of inclusion, and the population served, curriculum, teaching staff, infrastructure, and financing. Learning, assessment, a collaboration between teachers and parents, monitoring and supervision, and obstacles faced. the impact of implementing inclusion on the development/achievement of $A B K$ students at State Elementary School 01 Sungai Bambu. This study aims to describe the context, input, process, and product of the Inclusive Education program.

\section{METHOD}

This research at SDN Sungai Bambu 01 Pagi. The school has a very strategic location because it is close to urban areas and other educational providers such as junior and senior high schools so that people can easily access all directions. This type of research is evaluation research with the Context, Input, Process, Product (CIPP) model. Evaluative research is needed to design, refine and test the implementation of a program (Hartini et al., 2020). In this case, the researcher evaluates the inclusive education program in terms of Context, Input, Process, Product (CIPP). It is expected to describe inclusive education at SD N 01 Sungai Bambu, North Jakarta. Miles and Huberman suggest there are steps in data analysis, namely data reduction, data display, and conclusion drawing (Sugiyono, 2015). Data collection techniques were collected using primary data, namely, observation, Questionnaires / Questionnaires, and interviews. Secondary data collection was carried out through a documentation study. The documentation collected is in the form of archives for the implementation of inclusive education. The technique used to analyze the data is descriptive qualitative analysis.

\section{RESULT AND DISCUSSION}

\section{Result}

Context evaluation assesses the school program environment, legal basis, determination of inclusion providers, inclusion guidelines, socialization of inclusion, and the population served. The school program environment includes the vision and mission of inclusive education providers, the background and objectives of inclusive education. The legal basis contains laws and regulations relating to the implementation of inclusive education. The determination of inclusion providers is related to school operational permits in providing inclusive education. The inclusion guidelines are related to the inclusion organizer guidelines. Inclusion socialization includes socialization of the implementation of inclusion programs. While the served population consists of the types of special needs suited, the PPDB selection process, and the number of ABK students served. Document studies and interviews carried out data collection related to the inclusive education program environment. In the document study, no documents contained the vision and mission of implementing inclusive education at SDN 01. Apart from the absence of documents stating the vision and mission, there were also no documents that informed the background and objectives of implementing inclusive education. The results of interviews with school principals, viceprincipals, and homeroom teachers indicate that the purpose of the inclusive education program is to help develop children with special needs to socialize and learn independently. Another consideration behind this inclusive education program concerns that if children with special needs attend special schools or special schools, their social development will be hampered. The interview results with the homeroom teacher also stated that inclusive education was initially carried out by SDN 02 . SDN 02 was appointed to carry out inclusive education. The special schools in the area could no longer accommodate children with special needs, so SDN 02 was appointed to implement inclusive education. After the merger of SDN 02 with SDN 01, the status of inclusive education schools was given to SDN 01. Based on the results of the interviews, it can be concluded that the implementation of inclusive education at SDN 01 is the result of the joining of SDN 02 with SDN 01. The goal to be achieved. It is to develop the ability of ABK students to socialize both with fellow students and with the community. 
It collected data related to the legal basis for inclusive education at SDN 01, based on documentation studies and interviews. In the document study, it was not found that schools had documents containing the legal basis for implementing inclusive education at SDN 01. The results of interviews with school principals and homeroom teachers. It is stated that the legal basis for implementing inclusive education is the National Education Law, Law No. 20 of 2003. concerning the National Education System, in particular, Article 5 paragraph 1 and Article 51 concerning the equal rights of children with special needs to obtain quality ordinary and extraordinary education. The results of interviews with school principals, vice-principals, and homeroom teachers showed that the implementation of inclusive education at SDN 01 started with the joining of SDN 02 with SDN 01. Meanwhile, the performance of inclusive education at SDN 02 began with the appointment of SDN 02 schools by the Government. By joining SDN 02 with SDN 01, the inclusive education program is implemented by SDN 01. Based on the results of document studies and interviews, it can be concluded that based on SK 1910-01-01, SDN 01 can provide inclusive education with the condition of students with mild mental retardation. Guidelines for implementing inclusive education are an effort to organize the fulfillment of children's rights with special needs to obtain a quality education. They are collecting data related to the guidelines for implementing inclusive education at SDN 01, based on documentation studies and interviews. Based on the document, the school adheres to the eight standard guidelines issued by the Government. The results of the interviews, the eight guidelines are expected to help implement the learning that can shape students' attitudes, knowledge, and skills that are more consistent from the start so that they can develop into human resources who have religious, creative, innovative, and competitive attitudes. To follow and support implementing the eight standard guidelines issued by the Government, schools conduct training for classroom teachers.Based on the results of document studies and interviews, it can be concluded that schools follow eight guidelines for implementing inclusive education. One way to follow and support these eight guidelines is to conduct training for classroom teachers.

According to interviews with school principals and deputy principals, the socialization of the inclusive education program is carried out every year. Socialization is given during PPDB, and information about the implementation of inclusive education is given to all parents. The socialization carried out by the school is intended to explain the programs provided and the benefits that children with special needs will obtain. Based on document studies and interviews, it can be concluded that disseminating the inclusive school program at SDN 01. The school organizes a separate event during PPDB and provides leaflets containing upcoming inclusive education programs. Based on the document study, the number of students with special needs who were accepted was not only mentally retarded. ABK students with ADHD, deaf, and slow learners. Based on data from the field, the number of students in the $2019-2020$ school year with special needs students is 23 people from class I to class VI. Meanwhile, in the 2020-2021 school year, the number of students decreased to 14 people. From the number of existing ABK students, many developmentally disabled ABK students attend SDN 01. Based on the results of interviews with both the Principal, vice-principal, and homeroom teacher, most of the students with special needs at SDN 01 are slow learners. While the results of interviews with homeroom teachers, schools have not accepted children with special needs who are deaf and blind. The number of students accepted. Based on the Principal and deputy principal interviews, SDN 01 only agrees with a maximum of 2 students in each study group. Based on the results of document studies and interviews, it can be concluded that ABK students at SDN 01 have decreased. The dominant ABK students at SDN 01 are developmentally disabled children with special needs. The school itself applies government regulations in accepting ABK students, a maximum of 2 ABK students in each study group. At the selection stage, the school refers to the psychologist's recommendation and the student's age limit.

Curriculum data collection is used in document studies and interviews. Based on the document study, the inclusive education curriculum uses the 2013 curriculum. As for students with special needs, schools make changes to the implementation resistance. When viewed, the implementation of the curriculum for each student with special needs is different. That is adjusted to the condition of ABK students, so it is easy to understand and learn from ABK students. The interviews with both the Principal, viceprincipal, and homeroom teacher show that the implementation of inclusive education uses the National Standard Curriculum applicable in public schools. In supporting the needs of ABK students, the existing curriculum is modified according to the characteristics of each ABK student. As stated by the Principal, the curriculum used by the school remains the 2013 curriculum. As for students with special needs, the current curriculum is modified according to student conditions and input from GPK teachers. As for the modifications made. As conveyed by the homeroom teacher, the difficulty level was reduced according to the abilities of ABK students. In developing the curriculum, the school has a special team that evaluates and prepares the curriculum based on developments at the beginning of each new school year. Meanwhile, for the PPI, the class teacher did not make it. The PPI is compiled and driven by the accompanying teacher, whose implementation is carried out by each child's class teacher. Based on the results of document studies 
and interviews, it can be concluded that the curriculum used by SDN 01 schools in the 2013 curriculum. As for supporting ABK students, schools modify the curriculum according to the characteristics of each ABK student. Curriculum modification is carried out together with the accompanying teacher.

They are collecting data related to teaching staff, either through document studies and interviews. Based on the document study, the school has 19 teachers and four education personnel. For special assistant teachers, SDN 01 schools do not have permanent special assistant teachers. Meanwhile, based on interviews, SDN 01 schools do not have special assistant teachers who are permanent. Special assistant teachers are assigned from the National Education Office and only come once a week to provide special lessons tailored to the development of ABK students. To overcome the absence of special assistant teachers, schools send teachers to special training to assist students with special needs in learning. This training is carried out periodically and alternately. Based on document studies and interviews, it can be concluded that SDN 01 does not have a permanent special assistant teacher. To overcome this, the school sends teachers to attend special training periodically and alternately. They are collecting data related to facilities and infrastructure based on document studies and interviews. The presence of ABK students requires schools to prepare special infrastructure facilities according to the characteristics of students. Based on the document study, the school only has 15 classrooms. Each level consists of two classes and one particular class for ABK students when there is exceptional learning. In addition, the need for accessibility for ABK students only has handrails, while other infrastructures such as toilets are not available. In special classrooms, several tools are used during specific learning. Based on the interviews with school principals, vice principals, and homeroom teachers, it was revealed that the facilities and infrastructure needed by ABK students are still not optimal. Currently, the facilities and infrastructure available at SDN 01 schools are limited to particular rooms for ABK students when special accompanying teachers come to visit. Meanwhile, other facilities and infrastructure to support the daily activities of ABK students at school are still limited to handrails that help $\mathrm{ABK}$ students go up and down the school stairs.

Based on the results of document studies and interviews, it can be concluded that the facilities and infrastructure at SDN 01 are only ordinary classrooms, special study classrooms, and handrails for accessibility. Based on document studies, most of the funding for the performance of inclusive education is obtained from BOS funds. The BOS funds are used to finance additional teacher fees in making teaching aids used when learning with special needs students. Meanwhile, third-party assistance in terms of funding is only in the form of physical services, such as assistance with walking equipment. Based on the interview results, it was stated that the cost requirements in inclusive education schools were the same as regular schools in general. However, with additional elements such as GPK, infrastructure that must have accessibility requires financing that is not just the same as regular schools but must adjust. The Principal revealed that all sources of funding came from BOS and BOP. While the involvement of other parties in supporting the implementation of inclusive education is highly expected, especially supporting facilities such as learning aids and school principals and deputy principals convey that assistance has ever existed and is rarely given. Based on the results of document studies and interviews, it can be concluded that BOS and BOP funds are the primary sources of financing in the implementation of inclusive education.

In the setting of learning in inclusive schools, teachers generally make plans according to the characteristics of students. Based on the document study, the school makes learning guidelines for ABK students based on input from special assistant teachers. Each procedure for implementing education in the classroom is different based on the level and characteristics of ABK students. Meanwhile, the results of interviews with the deputy principal of the learning method were prepared by special assistant teachers. During the implementation of learning, learning media are sometimes made by teachers. Learning media is made according to ABK students' ability to understand and understand the teaching material provided. In terms of mentoring, ABK students are accompanied by a special assistant teacher at least once a week or when the accompanying teachers come to SDN 01 school. Regarding the development of ABK students, the teacher periodically coordinates with parents to inform the child's progress. Based on the study of documents and interviews, it can be concluded that a special assistant teacher prepares the learning method. In practice, the class teacher makes tools according to the characteristics of ABK students so that the learning provided can be understood and understood by ABK students.

The collaboration between teachers and parents is not documented, so they cannot analyze the document in-depth. While the results of the interviews mentioned, in the learning process, sometimes ABK students have difficulty. To find solutions to help the child's learning process, the teachers discussed a lot with special assistant teachers and other fellow teachers who also handled ABK students. In addition, the teachers also coordinate with parents. So that at home, the parents help the child repeat the learning process that has been received. Based on the results of interviews, it can be concluded that in overcoming and finding solutions to problems faced in handling ABK students, classroom teachers work closely with fellow teachers, special assistant teachers, and parents. Based on the final report document analysis, ABK 
students have different assessment descriptions from other general students. Meanwhile, there is no difference between students with special needs students and available students. Based on interviews with school principals, assessing student learning outcomes with special needs students is the same as other regular students. It is just that the description of the assessment is different from regular students. In addition, ABK students also receive special reports from special assistant teachers. This report concerns the developments that have been achieved and those that the child has not achieved. Based on the results of the study of documents and interviews, it was concluded that the completeness value of ABK students was the same as other general students. The only difference lies in the description of the assessment. In addition, ABK students also receive reports from special assistant teachers, which contain information on the developments experienced by ABK students.

Based on the document study, there are several certificates, and trophies won by ABK students when participating in the competition event. While the results of the interviews, delivered by both the principal and homeroom teacher, the school included ABK students in soccer and self-defense matches. Based on the results of document studies and interviews, it can be concluded that in building the selfconfidence of ABK students, schools include ABK students in various competitions according to their talents and abilities. Based on the results of the document study, it was noted that several times officers from the National Education Office visited to monitor the implementation and development of inclusive education at SDN 01. In addition, it was pointed out that there were talks between the officers of the National Education Office and the school staff in coordinating the direction of implementing inclusive education. Meanwhile, from the results of interviews with the Principal. Supervisors from the National Education Office often monitor and ask about children's progress with special needs and ongoing inclusive education programs. In addition, for special assistant teachers, monitoring from the inclusive POKJA service is also carried out. Based on the results of document studies and interviews, it can be concluded that the National Education Office monitors the implementation of inclusive education at SDN 01, and the National Education Office, together with the school, holds a discussion meeting to discuss the problems faced and how to overcome them.

The implementation of inclusive education at SDN 01 cannot be separated from blocks. Apart from the lack of facilities and infrastructure, learning materials that are difficult for ABK students to follow, and the lack of special assistant teachers. Of the many obstacles faced, the lack of special assistant teachers is the main obstacle for SDN 01. That can be seen from a study of documents related to the request from the school for permanent special assistant teachers. Based on the results of interviews with the principal, viceprincipal, and homeroom teacher. They said that even though the classroom teachers had been given training, the teachers could not provide full assistance to ABK students because they had to share mentoring with regular students. The school conveys how significant special assistant teachers are because they are needed during special education programs and accompany special needs students when studying in regular classes. Based on the results of document studies and interviews, it can be concluded that the main obstacle in implementing inclusive education at SDN 01 is the absence of special assistant teachers.

The goals of the inclusive education program are: first, children with special needs receive quality education according to their needs and abilities; second, creating an education system that respects diversity, is non-discriminatory, and friendly to all students. Based on the evaluation of documents, both the ABK student graduation certificates and several photos of activities carried out by the school. They have seen and the academic abilities that have been achieved, ABK students can socialize with other students and the community. While the results of interviews with the Principal, with the guidance and direction, students with special needs have maximally acquired the skills to learn in real life. Socialize well with other normal children and can jump in and mingle amid society. In addition, according to the vice-principal and homeroom teacher, ABK students can now appear in the community and socialize. In addition, in terms of academic achievement, both the principal and homeroom teacher said that some ABK students could continue to further education, either to junior high school or to MTS. In fact, according to the Principal, a child with special needs was accepted into one of his favorite junior high schools. Based on the results of document studies and interviews, it can be concluded that inclusive education helps the development of special needs students both in terms of academics and socializing. In addition, the impact of implementing inclusive education is also felt by regular students and the community. They can accept ABK students' presence by helping them socialize and develop, both by joking and answering questions posed by ABK students.

\section{Discussion}

School Objectives inclusive education program is intended to assist children with special needs in socializing and independence (Pratama et al., 2021a; Yada et al., 2021). SDN 01, a fusion of SDN 02, does not have a vision and mission. That describes the goals and objectives to be achieved from the inclusive 
education program. The vision and mission are the earliest standards to explain the goals and objectives achieved both an organization and a program (Shubeck et al., 2020; Szumski et al., 2017). In addition, the vision and mission must be realistic and easy to understand. Understood by all parties so that the goals and objectives formulated in the image and mission can be achieved. Therefore, it is crucial for SDN 01 schools to immediately develop the vision and mission of the inclusive education program and the goals and objectives to be achieved. The implementation of inclusive education at SDN 01 no longer because of compulsion due to the appointment. Nevertheless, because of the awareness to carry out the mandate of the 1945 Constitution and the National Education Law No. 20 of 2003.

As stated by the principal, vice-principal, and homeroom teacher, the determination to implement inclusive education at SDN 01 began with the joining of SDN 02 with SDN 01. The merging of the two schools impacted continuing inclusive education, namely by implementing it by SDN 01. Thus, it is not surprising that the management of SDN 01 always states that the determination of the SDN 01 school to provide inclusive education is due to the decision to combine SDN 02 with SDN 01. Even some parties in the SDN 01 school state that the operating permit for SDN 02 inclusive education is a license to administer Inclusive education is used by SDN 01. The determination of this implementation needs to be emphasized. Because this is closely related to the assistance that the Government will provide. Unclear stipulations significantly impact the performance of inclusive education at SDN 01, especially now that the Government is building schools with special needs around the area of SDN 01. The construction of special schools is undoubtedly in contradiction with the existing law. In the spirit of the law, the Government guarantees the equal rights of students with special needs to study together with other regular students (Cahyani, 2019; Habibi, 2017; Pratama et al., 2021b). For this reason, schools must emphasize the determination of inclusive education at SDN 01; not only that SDN 02 has joined, but it is true that SDN 01 is appointed and determined by the Government to provide inclusive education.

Guidelines for implementing inclusive education are implementation instructions that must be met by every school that will implement inclusive education (Diahwati et al., 2016; Hamidaturrohmah \& Mulyani, 2020b). The presence of facilities and infrastructure and supporting teaching and learning activities also provide a sense of security and motivation in children with special needs for the support provided (Suastariyani \& Tirtayani, 2020; Yunita et al., 2019). Therefore, it is imperative to adhere to the guidelines issued by the Government; schools also develop accompanying guidelines based on the condition of the school. It is crucial to adjust the guidelines for implementing the inclusive education program to school conditions to support government programs and school accountability. The program that will be run can help, provide a sense of security, and motivate children with special needs (Dewi et al., 2019; Praptiningrum, 2010). So that when socializing the program to the community, the community can understand and understand what inclusive education will run and how this education can have an impact on the development of their children.

Based on the results of interviews, it is said that there are times when schools accept ABK students regardless of the child's condition. During the implementation of the learning process, the school observes whether the ABK student can participate in the learning process or not. If students with special needs are unable, the school recommends the child to go to special schools. Of course, this is very detrimental to the students with special needs (Silfiasari, 2018; Winarsih, 2013). For this reason, it is necessary for schools from the start to make selections by allowing the ABK students to do trials during the year the learning process is running. By conducting tests from afar, it can help students and parents to choose the right school. As with other inclusive schools, SDN 01 uses the 2013 curriculum, which has been modified to be applied to inclusive education. Curriculum modification is done because children with special needs have different individual characteristics from other regular children (Diahwati et al., 2016; Hamidaturrohmah \& Mulyani, $2020 \mathrm{~b}$ ). In addition, the learning barriers experienced by children with special needs are not the same as those faced by ordinary children. For example, the learning experience of children with special needs who are deaf is undoubtedly not the same as the learning experience of those who are deaf. Where the ability in understanding learning who is speech-impaired may be better than those, who are deaf. Therefore, children with special needs who are deaf need a learning model in visuals or visual aids to help them understand their lessons. Even though the curriculum is adjusted, curriculum evaluation is still mandatory. It is instrumental in seeing how effective the curriculum is in guiding children and seeing the developments of the existing learning process.

In the learning process of ABK students, teachers carry out education programs that have been created and compiled by special assistant teachers. What has been going well is indeed good. Thus, students with special needs students can receive learning materials that follow the characteristics of special needs students (Suastariyani \& Tirtayani, 2020; Yunita et al., 2019). One of the obstacles faced by ABK students is the absence of accompanying teachers in learning in class. This difficulty is encountered because the teachers who teach cannot entirely focus on assisting them. Therefore, it is essential to have a companion 
teacher in the class. In addition, the presence of an assistant teacher once a week is minimal. Because ABK students need much special training that can help them become independent, the school needs to add special training hours for $\mathrm{ABK}$ students so that the development of ABK students can be achieved as expected.

The existence of inclusive education has directly grown the cognitive and psychomotor abilities of ABK students (Dewi et al., 2019; Praptiningrum, 2010). The students saw how they were allowed to develop and learn to live independently. The ABK students also feel the sense of security and motivation provided by the teachers and other regular students to socialize and mingle with them. The development of special needs students in dating is critical. With their ability to socialize with ABK students, it can be said that they have been able to live independently. The ability to socialize and live independently is the ultimate goal of the inclusive education program. With the achievement of implementing inclusive education, ABK students can be stated to live amid the broader community without worrying about their limitations. With the opportunity to be able to continue with higher education, it indicates that their abilities or skills can be improved. That certainly gives motivation for ABK students to be more developed and valuable for the wider community.

\section{CONCLUSION}

The implementation of inclusive education at SDN 01 was not supported by an infrastructure that was under the needs of ABK students, and there were no permanent special assistant teachers who could prepare teaching materials, guide and monitor the development of ABK student's education. The obstacles faced by SDN 01 show that schools cannot meet the eight inclusive education standards set by the Government. For this reason, from the results of the evaluation that has been carried out, schools must act so that the learning rights of students with special needs and regular students are not disturbed. The school immediately makes a vision and mission that contains the goals and objectives of inclusive education. With a measurable and clear vision and mission, it can encourage all implementing members of SDN 01 school education to realize the goals and objectives to be achieved. Schools make guidelines for the implementation of inclusive education that refer to school conditions.

\section{REFERENCES}

Batterbee, R. A. (2020). The inclusion of cognitive behavioural therapeutic components in the undergraduate nursing curriculum. A systematic integrative review of the evidence. Nurse Education Today, 94. https://doi.org/10.1016/j.nedt.2020.104567.

Cahyani, N. (2019). Psikodrama untuk Meningkatkan Empati Siswa di Sekolah Inklusif. Inklusi, 6(2), 259. https://doi.org/10.14421/ijds.060204.

Dewi, N. P. A. S., Tirtayani, L. A., \& Suniasih, N. W. (2019). Efektivitas Program Paud Inklusi Di Kota Denpasar Ditinjau Dari Aspek Konteks. Jurnal Pendidikan Anak Usia Dini Undiksha, 7(1). https://doi.org/10.23887/paud.v7i1.18731.

Diahwati, R., Hariyono, H., \& Hanurawan, F. (2016). Keterampilan Sosial Siswa Berkebutuhan Khusus Di Sekolah Dasar Inklusi. Jurnal Pendidikan : Teori , Penelitian Dan Pengembangan, 1(8), 1612-1620. https://doi.org/10.17977/jp.v1i8.6682.

Flores-tena, \& José, M. (2020). The Educational Inclusion in the Deficit of Attention of Elementary Students. International Journal of Educational Research Review, 265-273. https://doi.org/10.24331/ijere.747244.

Habibi, N. (2017). The Use of Flashcards in Improving Vocabulary Mastery of Students with Disability. Inklusi Journal Of Disability Studies, 121. https://doi.org/10.14421/ijds.040203.

Hamidaturrohmah, \& Mulyani, T. (2020a). Strategi Pembelajaran Jarak Jauh Siswa Berkebutuhan Khusus Di SD Inklusi Era Pandemi Covid-19. Elementary: Islamic Teacher Journal, 10(1). https://doi.org/10.21043/elementary.v8i2.7907.

Hamidaturrohmah, \& Mulyani, T. (2020b). Strategi Pembelajaran Jarak Jauh Siswa Berkebutuhan Khusus Di SD Inklusi Era Pandemi CoVID-19. Elementary: Islamic Teacher Journal, 10(1). https://doi.org/10.21043/elementary.v8i2.7907.

Hartini, H., Rugaiyah, R., \& Kahar, A. (2020). Evaluasi Program Pendidikan Pengembangan Spesialisasi Polri T.A. 2018 Di Sekolah Pimpinan Tingkat Pertama Polri. Visipena. https://doi.org/10.46244/visipena.v11i2.1299.

Heyder, A., Südkamp, A., \& Steinmayr, R. (2020). How are teachers' attitudes toward inclusion related to the social-emotional school experiences of students with and without special educational needs? Learning and Individual Differences, 77. https://doi.org/10.1016/j.lindif.2019.101776. 
Kim, S., Choe, I., \& Kaufman, J. C. (2019). The Development and Evaluation of The Effect of Creative ProblemSolving Program on Young Children's Creativity and Character. Thinking Skills and Creativity, 33(August), 100590. https://doi.org/10.1016/j.tsc.2019.100590.

Kratz, F., Patzina, A., Kleinert, C., \& Dietrich, H. (2019). Vocational education and employment: Explaining cohort variations in life course patterns. Social Inclusion, 7(3), 224-253. https://doi.org/10.17645/si.v7i3.2045.

Krischler, M., Cate, I. M. P., \& Krolak-Schwerdt, S. (2018). Mixed stereotype content and attitudes toward students with special educational needs and their inclusion in regular schools in Luxembourg. Research in Developmental Disabilities, 75. https://doi.org/10.1016/j.ridd.2018.02.007.

López, K. M. J. de, Feilberg, J., Baena, S., Lyons, R., \& Lyons, R. (2021). “So, I told him to look for friends!” Barriers and protecting factors that may facilitate inclusion for children with Language Disorder in everyday social settings: Cross-cultural qualitative interviews with parents. Research in Developmental Disabilities, 115. https://doi.org/10.1016/j.ridd.2021.103963.

Maqableh, M., \& Alia, M. (2021). Evaluation online learning of undergraduate students under lockdown amidst COVID-19 Pandemic: The online learning experience and students' satisfaction. Children and Youth Services Review, 128(1). https://doi.org/10.1016/j.childyouth.2021.106160.

Mullett, T. A., Rooholamini, S. N., Gilliam, C., \& McPhillips, H. (2021). Description of a novel curriculum on equity, diversity and inclusion for pediatric residents. Journal of the National Medical Association. https: //doi.org/10.1016/j.jnma.2021.05.014.

Mulyanto, B. S., Sadono, T., Koeswanti, H. D., Dasar, S., Wonodoyo, N., Tengah, J., Kristen, U., Wacana, S., \& Tengah, J. (2020). Evaluation of Critical Thinking Ability with Discovery Lerning Using Blended Learning Approach in Primary School. Journal of Educational Research and Evaluation, 9(2), 78-84. https://doi.org/10.15294/jere.v9i2.46135.

Pangemanan, D. H. C., Engka, J. N. A., \& Supit, S. (2013). Gambaran Kekuatan Otot Dan Fleksibilitas Sendi Ekstremitas Atas Dan Ekstremitas Bawah Pada Siswa/I Smkn 3 Manado. Jurnal Biomedik (Jbm), 4(3), 109-118. https://doi.org/10.35790/jbm.4.3.2012.1217.

Patel, K., Ansari, S., Hexom, B., \& Dissanayake, V. (2021). An Assessment of a Diversity, Inclusion, and Racial Equity Curriculum in Emergency Medicine Residency Training. Annals of Emergency Medicine, 78(4). https://doi.org/10.1016/j.annemergmed.2021.09.198.

Praptiningrum. (2010). Fenomena Penyelenggaraan Pendidikan Inklusif bagi Anak Berkebutuhan Khusus. JPK (Jurnal Pendidikan Khusus), 7(2). https://doi.org/10.21831/jpk.v7i2.774.

Pratama, F. I. P., Kristiyanto, A., \& Widyastono, H. (2021a). Character Values of Third Grade Slow Learner in Character Education at the Inclusive Elementary School. JPI, 10(2), 345-352. https://doi.org/10.23887/jpi-undiksha.v10i2.28838.

Pratama, Kristiyanto, A., \& Widyastono, H. (2021b). Character Values of Third Grade Slow Learner in Character Education at the Inclusive Elementary School. Jurnal Pendidikan Indonesia, 10(2), 345352. https://doi.org/10.23887/jpi-undiksha.v10i2.28838.

Ramachandra, S. S. (2020). A Comprehensive Template for Inclusion of Research in the Undergraduate Dental Curriculum. Health Professions Education, 6(2). https://doi.org/10.1016/j.hpe.2019.06.003.

Ro'fah, R., Hanjarwati, A., \& Suprihatiningrum, J. (2020). Is Online Learning Accessible During COVID-19 Pandemic? Voices and Experiences of UIN Sunan Kalijaga Students with Disabilities. In Nadwa (Vol. 14, Issue 1). https://doi.org/10.21580/nw.2020.14.1.5672.

Rudiyati, S. (2013). Peningkatan Kompetensi Guru Sekolah Inklusif Dalam Penanganan Anak Berkebutuhan Pendidikan Khusus Melalui Pembelajaran Kolaboratif. Cakrawala Pendidikan, 1(2). https://doi.org/10.21831/cp.v0i2.1488.

Savul, S., Ikram, A., Khan, M. A., \& Khan, M. A. (2021). Evaluation Of Infection Prevention And Control Training Workshops Using Kirkpatrick's Model. International Journal of Infectious Diseases, 1. https://doi.org/10.1016/j.ijid.2021.09.005.

Septianisa, S., \& Caninsti, R. (2018). Hubungan Self Efficacy Dengan Burnout Pada Guru Di Sekolah Dasar Inklusi. Jurnal Psikogenesis, 4(1). https://doi.org/10.24854/jps.v4i1.523.

Shofa, M. F. (2018). Implementasi Manajemen Pendidikan Inklusi di PAUD Inklusi Saymara Kartasura. IAN Surakarta, 3(2). https://doi.org/10.22515/attarbawi.v3i2.1337.

Shubeck, S. P., Newman, E. A., Vitous, C. A., Antunez, A. G., \& Dossett, L. A. (2020). Hiring Practices of US Academic Surgery Departments-Challenges and Opportunities for More Inclusive Hiring. Journal of Surgical Research, 254. https://doi.org/10.1016/j.jss.2020.03.054.

Silfiasari, S. P. (2018). Empati Dan Pemaafan Dalam Hubungan Pertemanan Siswa Regular Kepada Siswa Berkebutuhan Khusus (Abk) Di Sekolah Inklusif. Journal of Chemical Information and Modeling, 53(9), 1689-1699. https://doi.org/10.22219/jipt.v5i1.3886.

Sivaramakrishnan, D., Fitzsimons, C., Kelly, P., Ludwig, K., Mutrie, N., Saunders, D. H., \& Baker, G. (2019). The 
effects of yoga compared to active and inactive controls on physical function and health related quality of life in older adults- systematic review and meta-analysis of randomised controlled trials. International Journal of Behavioral Nutrition and Physical Activity, 16(1), 1-22. https://doi.org/10.1186/s12966-019-0789-2.

Suastariyani, N. K. N., \& Tirtayani, L. A. (2020). Survei Persepsi Orang Tua Mengenai Program Paud Inklusi Di Kota Denpasar Tahun 2020. Jurnal Pendidikan Anak Usia Dini Undiksha, 8(2). https://doi.org/10.23887/paud.v8i2.25156.

Sugiyono. (2015). Metode Penelitian Pendidikan (Pendekatan Kuantitatif, Kualitatif, dan R\&D). Alfa Beta.

Sulthon, S. (2019). Pendidikan Dasar Inklusif Di Kabupaten Pati: Harapan Dan Kenyataan. Journal of Disability Studies Inklusi, 6(1). https://doi.org/10.14421/ijds.060107.

Suprihatiningrum, J. (2016). Persepsi Siswa Difabel Terhadap Praktik Pendidikan Inklusif Di Sma Inklusi Di Yogyakarta. Journal of Disability Studies Inklusi, 3(2). https://doi.org/10.14421/ijds.030204.

Szumski, G., Smogorzewska, J., \& Karwowski, M. (2017). Academic achievement of students without special educational needs in inclusive classrooms: A meta-analysis. Educational Research Review, 21. https://doi.org/10.1016/j.edurev.2017.02.004.

Taylor, R. W., \& Ringlaben, R. P. (2012). Impacting Pre-service Teachers' Attitudes toward Inclusion. Higher Education Studies, 2(3). https://doi.org/10.5539/hes.v2n3p16.

Tempelaar, D. (2019). Assessment \& Evaluation in Higher Education Supporting the less-adaptive student: The role of learning analytics, formative assessment and blended learning. Assessment and Evaluation in Higher Education, 45(4). https: //doi.org/10.1080/02602938.2019.1677855.

Turgut, S., \& Turgut, I. G. (2018). The effects of cooperative learning on mathematics achievement in Turkey: A meta-analysis study. International Journal of Instruction, 11(3), 663-680. https://doi.org/10.12973/IJI.2018.11345A.

Widyastono, H. (2013). Strategi Implementasi Pendidikan Anti Korupsi di Sekolah. Jurnal Teknodik, 17(2). https://doi.org/10.32550/teknodik.v0i0.79.

Wijaya, H., Tari, E., Sumule, L., Weismann, I. T. J., \& Supartini, T. (2021). Online Learning Evaluation in Higher Education: Study Survey Method. Journal of Education Technology, 5(3), 401-408. https://doi.org/10.23887/jet.v5i3.35466.

Winanti, R., Purwanto, \& Khuriyah. (2021). Model Manajemen Pembelajaran Dari Rumah Untuk Pendidikan Berkarakter ( Studi Pada TK Islam Makarima Dan TK Inklusi Saymara Sukoharjo ). Jurnal Ilmiah Ekonomi Islam, 7(02), 648-660. https://doi.org/10.33394/jp.v7i4.2941.

Winarsih, M. (2013). Kompetensi Guru Reguler di Sekolah Inklusif dalam Pembelajaran Bagi Siswa Tunarungu. Perspektif Ilmu Pendidikan, 27(2), 97-103. https://doi.org/10.21009/PIP.272.3.

Yada, A., Björn, P. M., Savolainen, P., Kyttälä, M., \& Aro, M. (2021). Pre-service teachers' self-efficacy in implementing inclusive practices and resilience in Finland. Teaching and Teacher Education, 105. https://doi.org/10.1016/j.tate.2021.103398.

Yunita, E. I., Suneki, S., \& Wakhyudin, H. (2019). Manajemen Pendidikan Inklusi dalam Proses Pembelajaran dan Penanganan Guru Terhadap Anak Berkebutuhan Khusus. International Journal Of Elementary Education, 3(3). https://doi.org/10.23887/ijee.v3i3.19407. 